China Perspectives

$2010 / 3 \mid 2010$

Taiwan: The Consolidation of a Democratic and Distinct Society

\title{
Who Cares for Unions?
}

Public Attitudes toward Union Power in Taiwan, 1990-2005

\section{Chin-Fen Chang et Heng-Hao Chang}

\section{OpenEdition \\ Journals}

Édition électronique

URL : http://journals.openedition.org/chinaperspectives/5303

DOI : 10.4000/chinaperspectives.5303

ISSN : 1996-4617

Éditeur

Centre d'étude français sur la Chine contemporaine

Édition imprimée

Date de publication : 15 septembre 2010

ISSN : 2070-3449

\section{Référence électronique}

Chin-Fen Chang et Heng-Hao Chang, « Who Cares for Unions? », China Perspectives [En ligne], 2010/3 | 2010, mis en ligne le 01 septembre 2013, consulté le 28 octobre 2019. URL : http://

journals.openedition.org/chinaperspectives/5303; DOI : 10.4000/chinaperspectives.5303 


\author{
Public Attitudes toward Union Power in Taiwan, 1990-2005
}

\author{
CHIN-FEN CHANG AND HENG-HAO CHANG
}

This paper studies how the general public in Taiwan evaluates the power of unions and which groups of the population support stronger unionisation. We intend to compare changes in attitudes toward union strength in two ways. First, we examine whether macro-economic or political dynamics created changes in attitudes. Secondly, we analyse the direct effects of four types of independent variables on attitudes toward unions (individual or collective level, short-term or long-term), including gender, age, ethnicity, and education. Using four waves of the Taiwan Social Change Survey conducted between 1990 and 2005, we find that support for stronger unions rose markedly between 2000 and 2005 , expressing a higher awareness of the role of unions in labour relations, especially in the context of economic crisis or lower economic growth.

"According to Article 26 of the Labour Union Act, if a strike would damage public interests, [the state] can demand compulsory mediation. [...] Taiwan Railway Labour Union broke the intention and spirit of Article 26 of the Labour Union Act, using the holding of a meeting as a disguised means of going on a strike; this kind of law-skirting strike would hurt the image of the union and the labourers." ${ }^{(1)}$

$\mathrm{T}$ hose who witnessed the rule of Taiwan by the $\mathrm{Na}$ tionalist Party (Kuomintang, KMT) for over five decades before 2000 would not have felt surprised to hear the words quoted above, had they come from the KMT-it had been hostile to labour unions and had prohibited all labour movements until Martial Law was lifted in 1987. However the above-quoted newsletter was in fact distributed to the press by the Central Office of the Democratic Progressive Party (DPP) in 2003, when it was the ruling party in Taiwan. The cited remark came from the party's Deputy Secretary General, who was criticising the intended strike by locomotive drivers of the Taiwan Railway during the Mid-Autumn Festival holidays, as called by the Taiwan Railway Labour Union (Taitie gonghui). The deputy Secretary General became the Director of the Labour Affairs Council in a later cabinet reshuffling under the DPP regime. The fact that once in power the DPP's reaction to a potential strike was indistinguishable from KMT's shows the shared mentality of the ruling elites. To call off the potential strike, the ruling regime would on the one hand assert the illegality of the strike, and on the other hand use a self-assumed public disapproval to show the unpopularity of the movement. However, no one ever studied the actual reactions of the general public toward labour unions, labour movements, or other related issues.

The first Labour Union Law was implemented in Taiwan in 1929 during the Japanese colonial period. On the surface, the Act seems to acknowledge and protect the rights of unionisation and labour movements by workers. However, the Act was actually meant to regulate strike activities more than to facilitate labour's interests. After 1945, particularly due to the enactment of Martial Law, the rights of labour movements were prohibited for four decades until 1987. Under the Leninist state corporatism practiced by the KMT, nation-wide unions as well as those in state-owned enterprises were tightly controlled and supervised by either the Party itself or ethics offices (zhengfengshi) in firms or companies. These puppet unions effectively monitored workers' activities, promoted candidates of the KMT in political elections, and served as the propaganda machine of the Party or the capitalists-everything, in fact, but promoting the interests of their own members on matters such as wages or working conditions. It was only with the liberalisation of the regime at the end of the 1980s that workers were able to participate in various kinds of social movements, and the general public became aware, through the mass media, of the function of independent unions.

The enactment of the Labour Standard Law in 1984 and gradual changes in political culture contributed to the emergence of independent labour unions from the 1980s onward. After the lifting of Martial Law in 1987, labour activism reached its high point in 1988 and 1989 with numerous

1. Democratic Progressive Party (DPP), "Zhichi laodong sanquan, fandui youzou falü bianyuan de bagong" (Advocating three fundamental labour rights, opposing any strike on the edge of law), DPP Newsletter, 10 September 2003. 
Union members from a state-owned-enterprise raise their fists and shout slogans during a demonstration in the streets of Taipei on 1 May 2009 to protest the deteriorating job market. (C) AFP PHOTO / Sam YEH

strikes, petitions, sit-ins, and street demonstrations for various causes, including overtime pay, year-end bonuses, and working conditions. Many new independent unions were established, and some existing KMT or management-controlled unions turned into independent organisations. Soon afterward, however, the KMT started to repress independent unions by indicting union activists and blocking workers' strikes when then President Lee Teng-hui, under pressure from the conservative wing of the KMT, appointed retired military general Hau Pei-tsun as Premier. In addition, the Taiwanese economy's restructuring and an increasingly flexible labour market created new challenges for the Taiwanese labour movement.

The sudden lifting of Martial Law in 1987 opened up political space for Taiwan's civil society. Looking closely at the development of labour unions in Taiwan, however, even after the end of Martial Law, many labour unions in the public sector were still controlled by the KMT. Workers in the public sector enjoyed relatively good labour conditions, including job security, reasonable working hours, and retirement benefits. Class-consciousness was therefore relatively weak in public sector unions, and many unions took the road to autonomy only when they began facing the challenge of public sector privatisation in the 1990s. ${ }^{(2)}$

At the turn of the 1990s, the protests of unions in stateowned-enterprises became a major force in Taiwan's labour movement. For instance, in November 1989, a group of unions from public enterprises organised an "anti-privatisation" street demonstration. In May 1993, more than 10,000 workers from 14 public enterprises participated in demonstrations for "saving public enterprises and the common good of all citizens." In 1996, public enterprises launched a "Mayday for work" demonstration.

After the DPP became the ruling party in 2000, the labour movement succeeded in obtaining some legal reforms that, for example, allowed for more than one national federation of unions, the passage of the Protection for Workers Incurring Occupational Accidents Act, the Gender Equality in Employment Act, and the Protective Act for Mass Redundancy of Employees. But even though the DPP had long been friendly to unions and a few activists were recruited into the new governmental body, the business lobby managed to limit union efforts and increase its own influence on the new administration. As a result, the labour movement failed to promote substantial liberal legal reform under the DPP government. ${ }^{(3)}$

If the recognised role of the labour movement or unionisation is to promote the economic or political interests of indi-

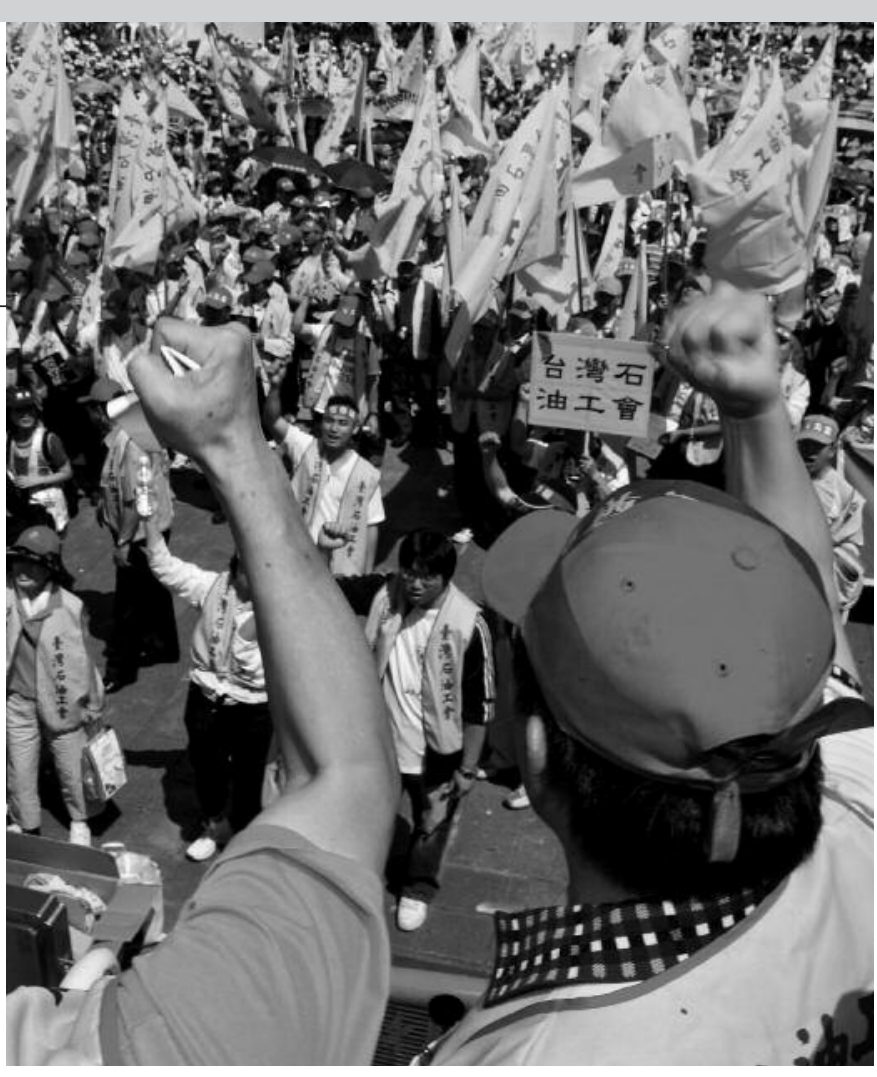

vidual unions or workers, union and working class consciousness remains an abstraction until it is embodied by workers' actions. Unionisation or collective action also reflects the degree of respect and tolerance of a democratic society toward voluntary resistance activities of civil society against the state or the capitalists. On many occasions, labour unions also participate in other social movements to express their concern and support for other civil and social rights, such as women's or environmental rights. This study therefore aims to consider what the general public thinks of labour unions in Taiwan, and who supports unionisation. Using four waves of the Taiwan Social Change Survey (Taiwan shehui biangian qiben diaocha), we will study how Taiwanese have viewed unions during the various phases of the liberalisation and democratisation era since 1987. Many factors may be associated with the public reaction toward unions, including a respondent's family background, social and economic status, and political orientation. Using data from different time points, we examine whether those individual factors provide consistent effects within different political and/or economic contexts.

\section{Literature review and theoretical framework}

Public opinion not only reflects public attitudes toward certain issues, but also provides inspiration for academic debate

2. Chin-fen Chang, Taiwan gongying shiye minyinghua: jingji misi de pipan (The privatization of state-owned enterprises in Taiwan: A critique of the economic myth), Taipei, Institute of Sociology, Academia Sinica, 2001.

3. Ming-sho Ho, "Neo-Centrist Labour Policy in Practice: The DPP and Taiwanese Working Class," in Dafydd Fell et al., What Has Changed? Taiwan Before and After the Change in Ruling Party, Wiesbaden, Harrassowitz, 2006, pp. 129-146. 
and suggestions for public policies, whether conservative or liberal, progressive or abiding by the status quo. ${ }^{(4)}$ Social organisations may thus be able to use the results of opinion surveys to push for the reform of public policies. The state apparatus has frequently posited as an absolute that labour strikes disrupt social order, and that union activities impede normal business operations and general economic development, but few studies have analysed public attitudes toward labour unions and possible changes in Taiwan. In the following, we briefly review the findings of previous studies concerning this topic in the Western World.

In a trend study on the eve of a crucial episode in the postwar history of labour unions in Western Europe, Roiser and Little show that British polls consistently showed strong public support for trade unions, but that more than half of union members themselves believed that trade unions were "too powerful." (5) In 1981, the proportion of union support was 61 percent, which was even higher than the rate a decade earlier (51 percent), and a high percentage of respondents still agreed that having trade unions was "a good thing in Britain." ${ }^{(6)}$ The British public therefore seemed to support the existence of labour unions but not the over-expansion of union power. This opinion poll may explain why Prime Minister Margaret Thatcher could bring about privatisation in the public sector-as in the case of British Telecom-and close coal mines despite fierce resistance and a long strike (1984-1985), and thus undermine the unions that were an important support for the Labour Party.

In the US, Tracy Chang used the 1991 General Social Survey to analyse the impact of various demographic factors and occupational characteristics on social attitudes toward labour unions. ${ }^{(7)}$ Her study pointed out that ethnic minorities, the working or self-employed class, those holding lower socioeconomic status, the unemployed and those experiencing career demotions tended to expect stronger influence from labour unions. She also found that neither educational achievement nor gender showed any significant effect on attitudes toward labour unions.

We shall use the findings from these previous studies as the basic guidelines for our analysis. However, public attitudes are not solely determined by individual and objective factors. Changes at the societal level and collective ideology play an important role in people's perception as well. To examine the various causes of political attitudes, we will refer to the socio-psychological concept of "public mood" as defined by Rahn, Kroeger, and Kite. ${ }^{(8)}$ They suggest a two-by-two typology to study the subject (short-term/long-term; individ$\mathrm{ual} /$ collective), and then classify the causes of public mood into four categories. ${ }^{(9)}$ For individual and short-term causes, they include personal experience and private mood. Individual experience consists of involvement in political activities, economic conditions, past dealings with government agencies, and criminal records. There are also long-term factors at the individual level, including personal socio-demographic characteristics such as age, sex, race/ethnicity, educational background, and class position. The authors also suggest that psychological reactions may have enduring effects on personal political attitudes. ${ }^{(1)}$ The factors in this category include personality and satisfaction with life.

Public mood is also affected by aggregate factors, including macro-economic performance and evaluations of politicians. These factors have short-term effects and might change when an economic recession ends or other leaders come to power. There are other collective elements with long-term and consistent effects on public attitudes, including national identity, patriotism, party orientation, and ideology. Their empirical findings generally support the hypotheses.

The merit of this typology is that it takes psychological factors into account simultaneously with personal and collective factors. As public attitudes represent subjective evaluations by individuals, their personal mood and feelings should be considered in the analysis. Another merit of the typology is that it considers both short-term and long-term factors. The short-term factors represent temporary conditions or experiences, which change when individuals take new positions or after political leaders step down. However, the distinction between short-term and long-term factors may not be as clear-cut as the typology shows. For instance, attitudes toward political leaders (a short-term factor) may actually be related to ideology regarding the power of the state (a longterm factor), and individual class position (a short-term factor) may also change with improvement or deterioration in the labour market. Mainly based on Rahn et al., our typology for the present study is listed in Figure 1. But unlike those authors, our paper will study changes in political atti-

4. Adam Swift et al., "Distributive Justice: Does It Matter What the People Think?", in James R. Kluegel et al., Social Justice and Political Change: Public Opinion in Capitalist and Post-Communist States, New York, de Gruyter, 1995, pp. 15-48.

5. Martin Roiser, Tim Little, "Public Opinion, Trade Unions and Industrial Relations," Journal of Occupational Psychology, vol. 59, 1986, pp. 259-272.

6. Ibid, p. 262.

7. Tracy F. H. Chang, "A Structural Model of Race, Gender, Class, and Attitudes toward Labour Unions," The Social Science Journal, vol. 40, 2003, pp. 189-200.

8. Wendy Rahn, Brian Kroeger, and Cynthia Kite, "A Framework for the Study of Public Mood," Political Psychology, vol. 17, no. 1, 1996, pp. 29-58.

9. Ibid., p. 38.

10. Ibid., p. 6. 
Figure 1. Causes Affecting Public Attitudes toward Union Power

\begin{tabular}{|c|c|c|}
\hline & Short-term & Long-term \\
\hline $\begin{array}{l}\text { Individual } \\
\text { Causes }\end{array}$ & $\begin{array}{l}\text { - Objective economic situations: occupational categories, and class } \\
\text { positions. } \\
\text { - Individual identity: class identity. }\end{array}$ & $\begin{array}{l}\text { - Social-demographic characteristics: } \\
\text { gender, ethnicity, age, and education. }\end{array}$ \\
\hline $\begin{array}{l}\text { Collective } \\
\text { Causes }\end{array}$ & $\begin{array}{l}\text { - Economic conditions: unemployment rate. } \\
\text { - Political conditions: Martial Law lifting, direct presidential election, } \\
\text { turnover of the ruling party. } \\
\text { - Emergence of labor movement. }\end{array}$ & $\begin{array}{l}\text { - Ideology: attitude toward social welfare } \\
\text { policy. } \\
\text { - Party orientation. }\end{array}$ \\
\hline
\end{tabular}

tudes and their causes to provide a more time-reliable explanatory model. We will also examine interactions between years and some key factors to resolve ambiguities in the lasting effects of short-term or long-term causes.

\section{Attitudes toward labour unions: Individual factors}

We will first discuss factors at the individual level, followed by political and economic changes over a period of 20 years in Taiwan.

Individual short-term factors mainly pertain to job status, the indicators of which include achievements (such as earnings or prestige) and job requirements (such as skills, expertise, or authority). Different jobs also imply different work cultures shaping their self-identification and ideology. ${ }^{(I I)}$ These characteristics as a whole might be represented by broad categories-that is, occupation or class.

Classifying the occupational structure into the blue-collar (manual) and white-collar (non-manual) dichotomy has been a common usage in cross-national studies of occupational segregation. ${ }^{(12)}$ While blue-collar employees work primarily in manual labour, white-collar employees mainly deal with clients or customers. According to Taiwanese official statistics, more than half of union members are in the mining and manufacturing industries. ${ }^{(1)}$ Thus it is reasonable to expect that bluecollar workers would be more likely to support stronger unions than those holding white-collar jobs. There are also differences within white-collar jobs. Higher-level white collar jobs require more human capital and have more autonomy, and work performance is not judged by quantity or on a short-term basis. Lower-level white collar workers, on the other hand, are mostly hired in service or routine jobs that couple low pay with long working hours and pressure. Professionals and other higher-ranking white collar workers rely more on their own qualifications in labour markets, while lower-level workers have to rely on a collective voice to improve work conditions.
The latter would therefore more likely support a stronger union than the more privileged white-collar workers.

In addition to the polarised classes-the bourgeoisie (employers) and the proletariat (the employed) used by Marx to characterise class relations under capitalism-we add the petite bourgeoisie because of the importance of this category in Taiwan's economic regime. Theoretically we would expect the working class to show stronger support for union power than the other classes. However, reviewing the economic development and the lives of the working class in Taiwan, one researcher observed in the 1980s that there is considerable mobility between workers, the petite bourgeoisie, and those working in family businesses. ${ }^{(14)}$ Following her argument, we could expect an equivalent level of support for strong labour unions among the petite bourgeoisie and employed workers. In contrast, Chu has concluded that because of the possibilities of moving upward in their careers, the Taiwanese working class lacks class consciousness and shows little commitment to unions and their actions. ${ }^{(15)}$ However, even if some workers do have the chance to become a boss or self-employed, their economic welfare may not significantly improve because of the meagre profits earned in a highly competitive market. ${ }^{(16)}$ We therefore expect that relative to employers, the working class and the self-employed should support strong unions.

In a departure from previous works, this paper also studies the attitudes of those who are not in the labour market, such

11. Michèle Lamont, The Dignity of Working Men: Morality and the Boundaries of Race, Class, and Immigration, New York, Russell Sage Foundation, 2000.

12. Maria Charles, David B. Grusky, Occupational Ghettos: The Worldwide Segregation of Women and Men, Stanford, Stanford University Press, 2004.

13. Data source: Council of Labour Affairs, Executive Yuan, Taiwan (http://statdb.cla.gov.tw/ statis/webproxy.aspx?sys=100; access date: 5 February 2010).

14. Hill Gates, Chinese Working-Class Lives: Getting by in Taiwan, Ithaca, NY, Cornell University Press, 1987, pp. 73-79.

15. Yin-wah Chu, "Democracy and Organized Labour in Taiwan: The 1986 Transition," Asian Survey, vol. 36, no. 5, 1996, pp. 495-510.

16. H. Gates, Chinese Working-Class Lives: Getting by in Taiwan, op. cit., p. 9. 
as homemakers, the unemployed, and adult students. As this group is rather heterogeneous, we do not have a specific hypothesis concerning the attitudes of homemakers or students toward union power. However, as stressed by Chang, respondents who are unemployed significantly support unions. ${ }^{(17)}$ As they find themselves in a weak position in the labour market, they can be expected to side against business and support strong unions.

Subjective class identity reflects the psychological mood of people, which is not solely decided by objective class position. Lamont and Hodson both find that the working class individuals they interviewed possessed strong self-respect and pride in working to make a living. ${ }^{(18)}$ Skeggs, who has studied British women in the service industry, found that because of the nature of their jobs, many identified themselves with the working class while also accepting the life orientations of the middle class. ${ }^{(19)}$ Based on these results, we expect that people identifying themselves as working class would more likely support labour unions becoming stronger.

Individual long-term factors mainly relate to ascribed characteristics, including demographic factors such as age and sex, and those representing family background, such as father's ethnicity. In the context of Taiwan, people who experienced rule under Martial Law might be less likely to support collective action to avoid unrest. In addition to this historical factor, life-course development may also play a role. As job stability and earnings are in general positively correlated with seniority, older workers are expected to be less enthusiastic about stronger unions than their younger counterparts.

As the previous study indicates, it is not easy to identify the relationship between gender and attitude toward unions, ${ }^{(20)}$ which might be a result of occupational characteristics. Blue-collar workers are primarily male, with women heavily concentrated in the service industries. There is another explanation for the possible difference in attitudes between women and men. A study by Ho Ming-sho suggests that the masculinity underlining the process of union solidarity formation might make female workers feel uneasy and discriminated against in unions. ${ }^{(21)}$ Thus, we hypothesise that women may react less positively to the function of unions and offer less support to unions than men.

In Taiwan, ethnicity is another important factor contributing to political behaviour and attitudes. ${ }^{(22)}$ On the one hand, ethnicity is significantly related to job location. For historical and political reasons, mainlanders (waishengren) are more likely to work in the public sector (governmental agen- cies or state-owned enterprises) than Taiwanese, ${ }^{(23)}$ while Hokkiens (or Hoklo [fulao], Minnanren) and Hakkas (kejia) are disproportionately represented in the manufacturing and primary industries and commerce as well as among the self-employed. Historical experience might also be an important factor affecting attitudes toward public issues in Taiwan's case. The long-term one-party rule of the KMT resulted in a high percentage of mainlanders in highranking official positions, particularly in central government. Because unions usually challenged state policy, mainlanders should be less likely to support unions, especially before the regime transition in 2000.

As to the association between education and attitudes toward unionisation, we expect that the more people are educated, the better they can appreciate the social power of civil society and sympathise with the position of the disadvantaged in the labour markets. Thus higher educational achievement should be positively associated with support for stronger union power.

\section{Attitudes toward labour unions: Collective factors}

Based on the scheme of Rahn et al., ${ }^{(24)}$ we treat aggregate economic and political contexts as short-term factors, and ideology and partisanship as long-term factors. Taiwan has experienced unprecedented political and social transformation since the second half of the 1980s, including the lifting of Martial Law, democratic transition, the presidential direct election, and party alternation in power. We provide a brief review of these changes below.

In general, Taiwan's democratic transition can be roughly divided into four periods: liberalisation (late 1980 to June 1987), a period of uncertainty (July 1987 to July 1988),

17. T. Chang, "A Structural Model of Race, Gender, Class, and Attitudes toward Labour Unions," art.. cit.

18. M. Lamont, op. cit., p. 8; Randy Hodson, Dignity at Work, Cambridge, Cambridge University Press, 2001.

19. Beverley Skeggs, Formation of Class and Gender: Becoming Respectable, London, Sage 1997

20. T. Chang, "A Structural Model of Race, Gender, Class, and Attitudes toward Labour Unions," art. cit., p. 6.

21. Ming-sho Ho, "Masculinity in Taiwan's Labour Union Movement," Taiwanese Journal of Sociology, vol. 36, 2006, pp. 65-108.

22. David D. Yang, "Class, Ethnicity, and the Mass Politics of Taiwan's Democratic Transition," World Politics, vol. 59, no. 4, 2007, pp. 503-538.

23. Yun Fan, Chin-fen Chang, "The Effects of Social Structural Positions on Ethnic Differences of Educational Achievements in Taiwan," Taiwan: A Radical Quarterly in Social Studies, 2010 (forthcoming).

24. W. Rahn et al., "A Framework for the Study of Public Mood," art. cit., p. 6. 
democratic transition (July 1988 to December 1994), and democratic consolidation (1995 and beyond). ${ }^{(25)}$ During the end of the first phase, thousands of street demonstrations were held by various social groups, including environmentalists, women's movement activists, aboriginals, farmers, and teachers. ${ }^{(26)}$ Labor movements started in 1988 and soon reached a peak within a few months. The former Director of the Council of Labour Affairs publicly remarked that he was shocked by the series of labour strikes occurring in the late 1980s, a development unthinkable under the control of the KMT corporatist regime previously. ${ }^{(27)}$

On the one hand, as mentioned above concerning the UK, if labour strikes against privatisation do not attract public support, we would expect that at the peak of protests against privatisation (especially in the mid 2000s), the public would show less support for union power. On the other hand, bad economic conditions create tight job markets for workers. Earnings, upward mobility, and job vacancies are all reduced or held back when a recession or slack business occurs. Many workers may even lose their jobs after downsizing or plant closures. It is therefore reasonable to expect that public support for union power would be stronger in a period of economic downturn than in times of economic prosperity. According to Rahn et al., public attitudes of individual respondents do not vary only with objective factors or individual characteristics. ${ }^{(28)}$ There are also collective mentalities that create consistent attitudes toward certain parties, policies, or beliefs. Party orientation is one of them, as is ideology. Therefore we will first discuss the impact of party orientation.

The first presidential direct election in Taiwan was held in 1996, and Lee Teng-hui, the KMT candidate, won the election. Although there were uncertainties and even backlashes in the early 1990s, this period opened up an era of democratic consolidation by being more liberal, socially and politically speaking. In the 2000 election, Chen Shuibian, the DPP candidate, won the presidential election, defeating the KMT, which had been the ruling party since the end of World War II.

The KMT had suppressed and controlled civic organisations, including labour unions, until the end of Martial Law in 1987, leading to strong criticism of the regime among workers. Some labour activists, such as members of the Taiwan Labour Front, had close relations with the DPP in the process of democratic transition. We would therefore expect that when the KMT was in power, supporters of the KMT or other parties relatively favourable to unification with China or disinclined toward independence would be less likely to support strong labour union power. When the DPP was in power in 2000, some former labour activists had the chance to become government officials and influence the state apparatus from within. But their attitudes toward union organisations and labour actions may have changed because of their new political positions in the regime. Thus, we expect that supporters of the DPP or other pro-Taiwan-independence parties were mostly likely to support unions when the KMT was in power, but that they might have been reluctant to support unions when the DPP was in power.

Not everyone has consistent views regarding policies or social events, but some do hold ideological opinions about governmental policies. Opinions regarding the welfare system might be a good case in point. In general, individuals who oppose excessive state spending on family, health, or unemployment subsidies are labelled as conservatives. These people are also inclined to believe in a laisser-faire economy and free competition in labour markets. In contrast, people who hold liberal viewpoints are likely to attribute personal misfortunes to structural factors and support a larger share of the budget for those in need. Following this logic, we would expect that people who support a welfare system would likely support stronger unions, while people who believe that welfare policies reduce the drive for success would give little support to a stronger collective voice (viewed as a threat to "normal" business operations).

\section{Interactions between collective and individual factors}

Theoretically, public attitudes toward political issues, leaders, or certain policies would be likely to change under various external political or economic conditions. In the case of opinions regarding union power in particular, we expect that the effect of personal job position and party orientation would be contingent on political and/or social conditions. In Figure 2 we list changes in economic and political conditions for the past 28 years. There are four dots specified on the $\mathrm{X}$ axis in Figure 2, which respectively represent the year of

25. Hsin-Huang Michael Hsiao, Hagen Koo, "The Middle Classes and Democratization," in Larry Diamond et al., Consolidating the Third Wave Democracies: Themes and Perspective, Baltimore, MD, Johns Hopkins University Press, 1997, pp. 312-333.

26. Mau-Kuei Chang, Shehui yundong yu zhengzhi zhuanhua (Social movements and political transformation), Taipei, Guojia zhengce yanjiu ziliao zhongxin (Data Center of National Policy Research, Chang Yung-Fa Foundation, 1989.

27. Ming-sho Ho, "A Working-Class Movement without Class Identity: Taiwan's Independent Labour Union Movement and the Limit of Brotherhood," Taiwan: A Radical Quarterly in Social Studies, no. 72, 2008, pp. 49-91.

28. W. Rahn et al., "A Framework for the Study of Public Mood," art. cit., p. 6. 
Figure 2. Trends of Political Transition, Economic Performance and Labor Compensations in Taiwan, 1980-2007

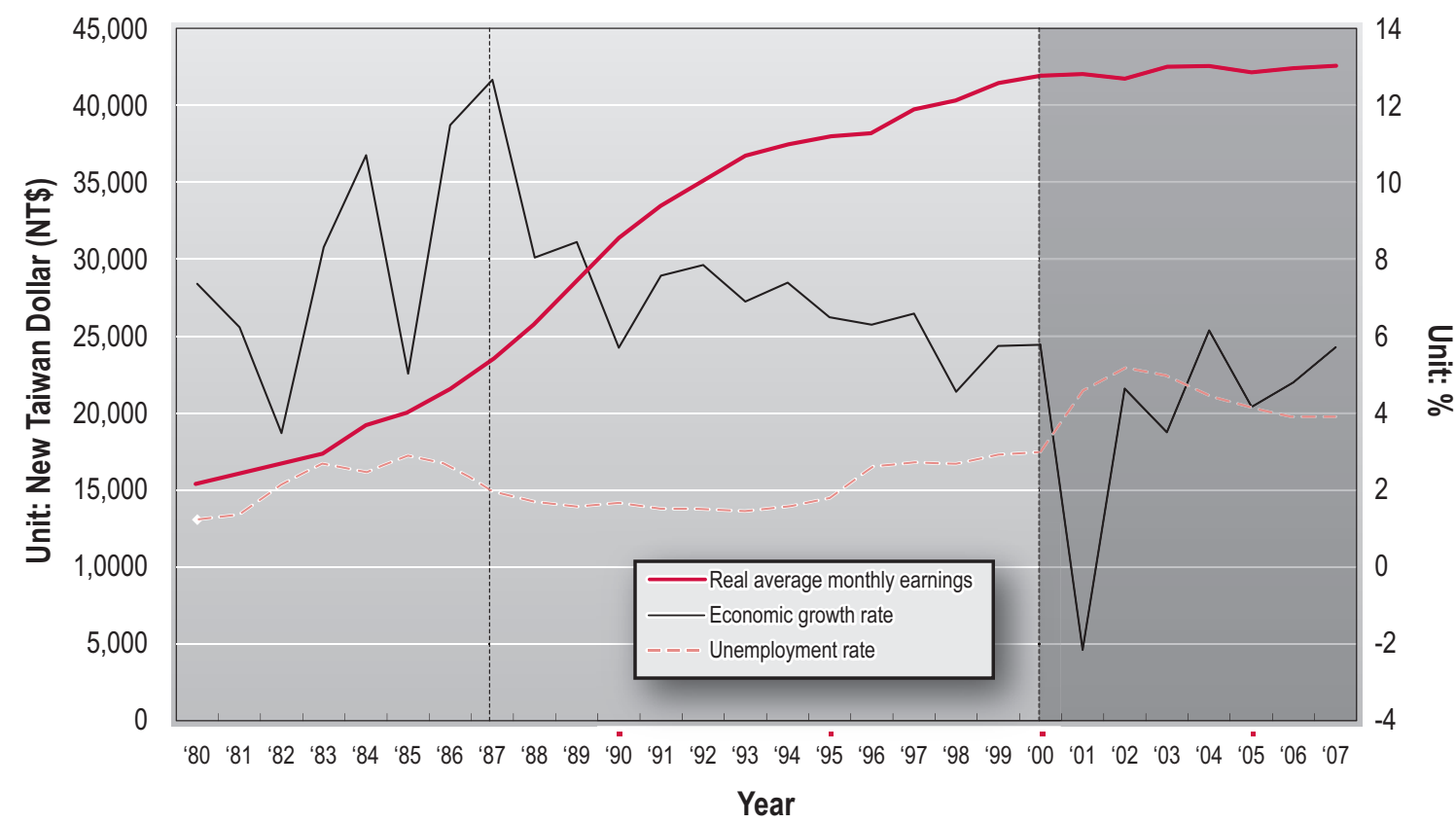

Source: National Accounts Yearbook, 2008; Price Statistics Monthly, No. 408, 444; On-line Database of Earnings and Productivity Statistics (http://www.dgbas.gov.tw/ct.asp?xltem=1135\&ctNode=3253; access date: 6 November 2008); and Yearbook of Manpower Survey Results, 2008. Note: The DPP took the place of the KMT as the ruling party in 2000 to 2008 , which is marked in grey.

the survey data (see the next section) used in the analysis. Although there was no lack of turmoil, the economy grew very rapidly before 1990 , but the growth rate has remained below 8 percent since then, and has averaged below 6 percent since 1998. Generally speaking, real earnings steadily increased during this period up until 2000, when they started to stagnate. However, workers also experienced increased unemployment after the mid-1990s, and the situation deteriorated further after 2000. Taiwanese export-led economic development has been heavily affected by global economic and political events during this period.

The year 1990 marked the transition to political democracy in Taiwan, and also a global economic recession due to the abrupt rise in oil prices during the first Gulf War. Taiwanese witnessed much better economic conditions in 1995 in terms of CPI (consumer price index)-adjusted earnings and relatively stable economic growth, but also experienced an increasing unemployment rate. In 2000, the DPP made history in Taiwanese politics by winning the presidential election. Unfortunately this year was also the beginning of a short period of recession due to the bursting of the dot-com bubble in the US, and unemployment rapidly increased in
Taiwan. While the general economic performance was good in 2005, real earnings for workers remained unchanged.

Turning to the interactions, we expect the impact of occupation on personal attitudes toward unions to vary in different survey years. We expect that lower-ranking workers, blue-collar, or lower white-collar workers, would strongly support an increase in union influence in years of poor economic performance such as 2000 and 2005 . We would not expect the attitudes of higher-level white-collar workers to change over time, as they are less likely to rely on unions to improve their benefits.

As to the interactions between class position and time period, we have two contradictory hypotheses. From the political side, we expect to find significant class differences in attitudes toward unions in 1990 and 1995, but these would probably diminish in 2000 and 2005. The main reason is the traditionally higher support for the DPP or other proTaiwan-independence parties among the petite bourgeoisie and the working class. As the DPP became the ruling party in 2000 and remained in this position after the subsequent election, these two classes would reduce their support for stronger unionisation. However, on the economic side we expect the working class to continue to support stronger 
union power during the economic downturns-that is, in 2000 and 2005.

The third item of interaction is between year and party preference. As we discuss above, in addition to pro-democracy movements, the DPP had been a major force in labour movements during the Martial Law era. Compared with the KMT, the DPP had strong ties with union organisations and industrial labour unions in several state-owned enterprises. Supporters of the DPP are expected to have wished to see greater union power during the rule of the KMT. However, when the DPP won the elections in 2000 and re-elections in 2004, its voters are likely to have shown support for the new regime and are less likely to have supported strong unions.

\section{Data, analytical approaches and variables}

The data used in the analyses come from four waves of the Taiwan Social Change Survey (TSCS) conducted in 1990 (with a sample size of 2,531 respondents), 1995 (2,093), $2000(1,960)$, and $2005(2,171)$. TSCS started the nationwide sampling survey in 1984. In the four surveys, participants were asked to consider whether the power and influence of workers' unions should be greater or less. ${ }^{(29)}$ Since respondents were sampled differently in each survey, the combined data is suitable for comparing changes in attitude over time. ${ }^{(30)}$ By including the age groups in the analytic models for each year we can test both age and cohort effects. ${ }^{(31)}$

This paper intends to compare changes in attitude toward union strength in two ways. We first examine whether macro-economic or political dynamics created changes in attitudes. The year 1990 is considered a period of democratic transformation. Political democracy increased in 1995 and further consolidated in 2000 when the DPP replaced the KMT as the ruling party. The DPP was still the ruling party in 2005 and experienced strong anti-privatisation movements the year before. We expect the general supportive attitude toward labour unions to have reached a peak in 1990 and to have diminished over the years.

The second approach focuses on the direct effect of independent variables on attitudes toward the influence of unions. Following the typology of Rahn et al., we consider four types of variables in the analysis (individual or collective level, short-term or long-term) and for individual, longterm variables we include gender, age, ethnicity, and education. Respondents are classified into three categories of ethnicity based on father's ethnic background: Hakka,
Hokkien, and mainlander. Educational achievements consist of four categories: primary school or less, attended or finished junior high school, attended or graduated from senior high school, and attended or graduated from college or university or a higher degree.

As to individual short-term factors, we include occupational and class position and subjective class identification. There are three categories to represent occupational structure: higher-status white-collar jobs, lower-status white collar, and blue-collar. Concerning class structure, there are four groups: employers, petite bourgeoisie, the working class, and nonemployed (the unemployed, students, and full-time homemakers). Subjective class identification also has four types: lower class, working class, lower-middle/middle, and uppermiddle/upper.

For collective, long-term factors, we include partisanship and ideology in the models. The KMT and DPP are the two major parties in Taiwan. Over the last 20 years there have emerged a few smaller parties, e.g., the New Party, the People-First Party, and the Taiwan Solidarity Union (TSU). The political ideology of the first two is close to that of the KMT, while the TSU has allied with the DPP. We thus combine supporters of the KMT, New Party, and People-First Party as Pan-Blue (fanlan), and those voting DPP, TSUP or other pro-Taiwan-independence parties as Pan-Green (fanlü). The third category includes respondents who did not identify with either the Pan-Blue or the Pan-Green.

The other aggregate and fixed factor deals with ideology and opinions regarding the welfare system. In all four surveys the respondents were asked to comment on the following assumption: If there is good social security, people will work less hard. We include one variable to represent macro and short-term factors. Since there are only four time points in the analysis, using the national unemployment rate for each year will not

29. There are more members in occupational unions than in industrial unions in Taiwan. The main purpose of occupational unions is to handle labour and health insurance for members. However, we do not think the difference in union membership should affect the validity of this question and the analytical results for two reasons. First, most respondents were not members of either occupational or industrial unions, according to the results of the Taiwan Social Change Survey in 2005 (Ying-Hwa Chang, Yang-Chih Fu [eds.], Taiwan Social Change Survey Report, No. 5-1, Taipei, Institute of Sociology, Academia Sinica, 2006: 332). Secondly, except for the survey in 2005, all earlier surveys put this question in a cluster of questions concerning the respondents' general social and economic attitudes, such as their opinions regarding the welfare system or toward the government's intervention in economic affairs. The respondents were expected to express a general view regarding the strength of unions but not regarding the unions they belonged to. We thank an anonymous reviewer for bringing this issue to our attention.

30. Glenn Firebaugh, Seven Rules for Social Research, Princeton, Princeton University Press, 2008, p.181.

31. For readers unfamiliar with statistics, the cohort effect is equal to adding the effects of age to period effects. 
Figure 3. Public Attitudes toward Union Power in 1990, 1995, 2000 and 2005

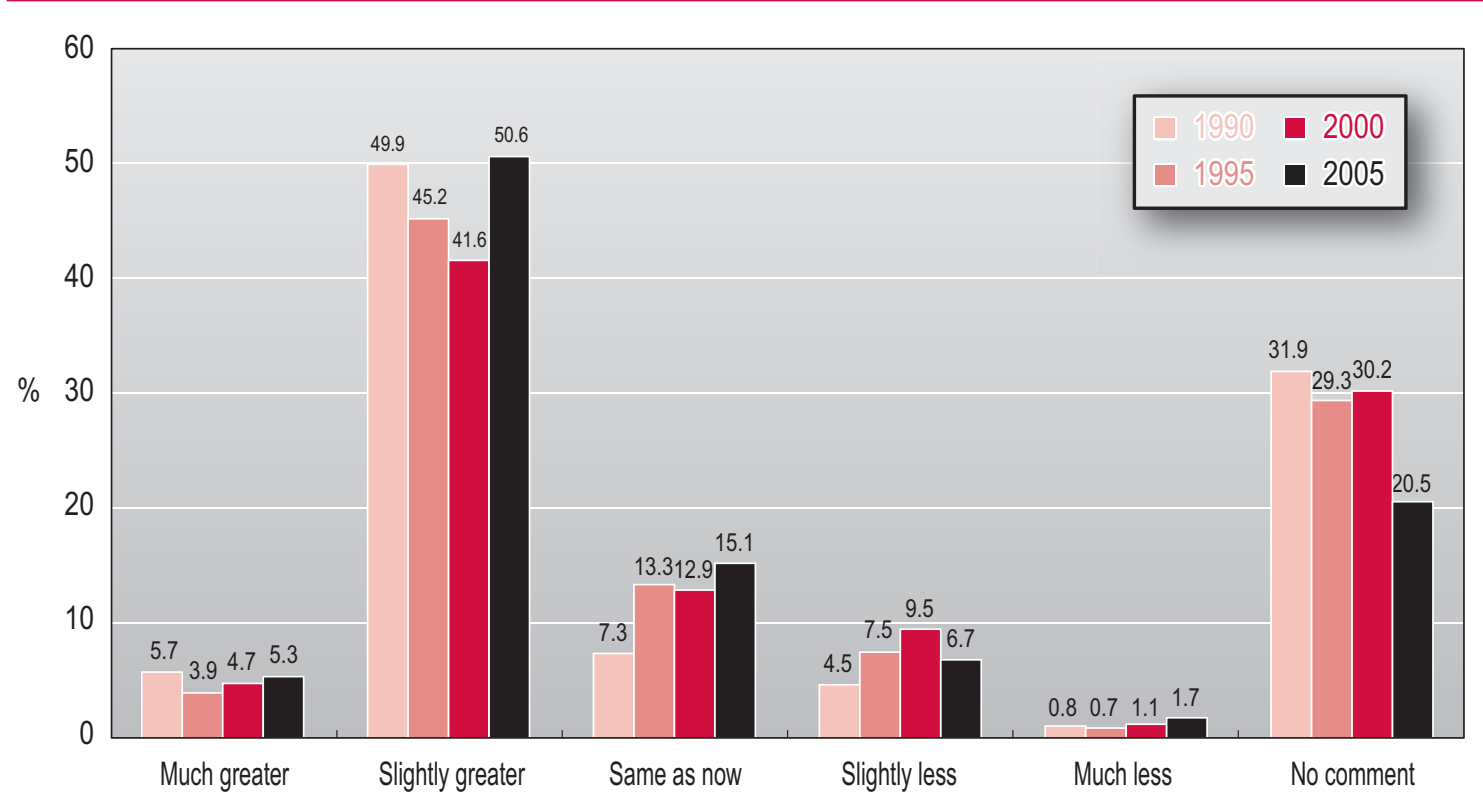

In our society, should the influence of workers' unions be greater or less?

Source: Taiwan Social Change Survey.

show much variation. Instead, the paper uses the regional unemployment rate to measure changes in economic conditions over time and in different areas. The variable is constructed by identifying the registered address of respondents and matching it with the regional (city or county) unemployment rate. ${ }^{(32)}$ The same method is applied to all four surveys. Referring to Tracy Chang's findings that the unemployed significantly support union power in the US, ${ }^{(33)}$ we expected similar trends in Taiwan.

The second and third approaches share the same multinomial logistic model in the analysis. For the second approach we are interested in the direct effect of respective independent variables and will examine the odds ratios of respective variables only. The third approach focuses on the interaction between year and individual job position and party preference (explained below). We compare the odds ratios of interaction effects together with main effects.

\section{Findings}

\section{Frequency distribution of attitudes toward unionisation over time}

As to the question of attitudes regarding union power, Figure 3 shows that Taiwanese consistently agreed that labour unions' influence should be stronger. In comparison, a far lower percentage of respondents supported less or much less influence for unions; even at its peak in 2000, this percentage was only 10.6 percent. This result should be very encouraging for union members or labour movement activists, even if another substantial proportion of respondents indicated either ignorance of or indifference to this issue by choosing "no comment" (in any case, this item decreased from 31.9 percent in 1990 to 20.5 percent in 2005). Public support for stronger unions peaked in 2005, reaching a level even higher than in 1990, just three years after society had been relieved of the authoritarian rule of the KMT.

\section{Multinomial logistic analysis: Main effects of independent variables}

Table 1 lists descriptive statistics of independent variables used in the multivariate analysis. Since most results can be

32. We are aware that respondents may not live in the same place as where they registered for voting or other purposes. According to a previous study, various studies have found the mismatch varying from 10 to 12 percent (Hsing-Yi Chang et al., "Comparisons among the Household Registry, Stay, and Migrated Populations in Taiwan: Evidence from the Data of 2001 Taiwan National Health Interview Survey," Survey Research, vol. 14, 2003, pp. 5-29).

33. T. Chang, "A Structural Model of Race, Gender, Class, and Attitudes toward Labour Unions," art. cit., p. 6 
Table 1. Descriptive Statistics of Independent Variables

\begin{tabular}{|c|c|c|c|c|c|}
\hline & Average & 1990 & 1995 & 2000 & 2005 \\
\hline Number of respondents & & 2,115 & 1,597 & 1,573 & 1,757 \\
\hline \multicolumn{6}{|l|}{ Independent variables } \\
\hline \multicolumn{6}{|l|}{ Gender } \\
\hline Female & 50.2 & 49.8 & 49.5 & 50.2 & 51.5 \\
\hline Male & 49.8 & 50.2 & 50.5 & 49.8 & 48.5 \\
\hline Age (mean; S.D.) & $39.9(13.2)$ & $36.9(11.1)$ & $40.4(12.5)$ & $42.0(13.8)$ & $41.3(14.9)$ \\
\hline \multicolumn{6}{|l|}{ Ethnicities } \\
\hline Hokkien of Taiwan & 74.0 & 74.2 & 70.5 & 78.9 & 72.4 \\
\hline Hakka of Taiwan & 13.1 & 13.6 & 15.1 & 9.1 & 14.2 \\
\hline Mainlander & 13.0 & 12.2 & 14.4 & 12.0 & 13.4 \\
\hline \multicolumn{6}{|l|}{ Education } \\
\hline Primary school or less & 26.3 & 30.4 & 26.7 & 28.5 & 18.8 \\
\hline Junior high school & 14.8 & 16.8 & 16.0 & 14.4 & 11.7 \\
\hline Senior high school & 36.1 & 36.3 & 37.7 & 35.0 & 35.5 \\
\hline College or higher & 22.8 & 16.5 & 19.7 & 22.1 & 33.9 \\
\hline \multicolumn{6}{|l|}{ Occupations } \\
\hline Higher white-collar & 12.6 & 11.6 & 12.2 & 14.2 & 12.6 \\
\hline Lower white-collar & 31.8 & 29.1 & 31.1 & 29.4 & 37.9 \\
\hline Blue-collar & 27.8 & 26.6 & 30.6 & 30.3 & 24.3 \\
\hline Non-employed & 27.9 & 32.7 & 26.1 & 26.1 & 25.2 \\
\hline \multicolumn{6}{|l|}{ Classes } \\
\hline Employer & 9.3 & 8.7 & 14.8 & 8.3 & 5.9 \\
\hline Petite bourgeoisie & 11.5 & 14.9 & 9.1 & 12.6 & 8.7 \\
\hline Labor & 51.3 & 43.6 & 50.0 & 53.1 & 60.3 \\
\hline Non-employed & 27.9 & 32.7 & 26.1 & 26.1 & 25.2 \\
\hline \multicolumn{6}{|l|}{ Subjective class identification } \\
\hline Lower class & 8.0 & 9.2 & 8.9 & 8.3 & 5.3 \\
\hline Working class & 20.2 & 27.7 & 17.4 & 20.2 & 13.8 \\
\hline Lower-middle or middle class & 58.2 & 52.5 & 62.4 & 60.3 & 59.4 \\
\hline Upper-middle or upper class & 13.7 & 10.6 & 11.4 & 11.2 & 21.5 \\
\hline \multicolumn{6}{|l|}{ Party orientation } \\
\hline Pan-Blue & 35.3 & 36.8 & 54.5 & 30.7 & 19.9 \\
\hline Pan-Green & 17.4 & 6.1 & 16.5 & 35.0 & 16.1 \\
\hline Others & 47.4 & 57.1 & 29.0 & 34.3 & 64.0 \\
\hline \multicolumn{6}{|c|}{$\begin{array}{l}\text { Whether in agreement with the saying: } \\
\text { "People will be less willing to work hard if there is good social } \\
\text { welfare." }\end{array}$} \\
\hline Agree & 25.5 & 14.6 & 21.8 & 30.3 & 37.6 \\
\hline No comment & 5.2 & 7.5 & 5.7 & 3.8 & 3.4 \\
\hline Disagree & 69.3 & 77.9 & 72.5 & 65.9 & 59.1 \\
\hline Unemployment rate (mean [\%]; S.D.) & $2.6(1.1)$ & $1.7(.4)$ & $1.9(.4)$ & $3.0(.7)$ & $4.1(.1)$ \\
\hline
\end{tabular}


easily interpreted, we discuss selective findings only. As we would expect, the average education level has increased over the last 20 years in Taiwan. Consistent with the transformation of the employment structure in Taiwan, the proportion of white-collar workers increased over the years, especially among the lower-ranking category. The proportion of blue-collar workers remained an average of 28 percent of total employed persons during this period. As to distribution among different classes, the proportion of capitalists or petite bourgeoisie decreased, while the greatest employment is found in the private sector. Table 1 also shows that the KMT or Pan-Blue has lost supporters over years, while Pan-Green or DPP supporters increased in terms of percentage. However even the Pan-Greens experienced a shrinkage of membership in 2005.

The multinomial logistic analysis combines the data from the surveys conducted in 1990, 1995, 2000, and 2005. The dependent variable is the public attitude toward the influence of labour unions. We simplified the original five items into three (should this influence be greater, less, or remain the same, and no comment), and we used the second item as the comparison group. Thus, when the coefficients of independent variables are positive (or negative), it means that the respondents with those characteristics are inclined to support greater (or less) union power.

According to Table 2, men, older people, and those who believe that good social welfare makes people lazy all have lower probabilities of supporting strong unions. The working class and Pan-Green supporters are more likely to favour powerful unions than their opposites (upper-middle/upper class, and PanBlue supporters). As to the time effect, after controlling for other variables, Taiwanese seemed less likely to support strong union power in 2000 and 2005 than in 1990.

As to who is more or less likely to show indifference or unfamiliarity with the issue, the results in Table 2 show that older people, those with little formal education, those
Figure 4. Added Odds Ratios of Main and Interaction Effects of the Support for Stronger Union Power by Occupation, Class, and Party Inclination in 1990, 1995, 2000 and 2005

(a) Interactions between Occupation and Year

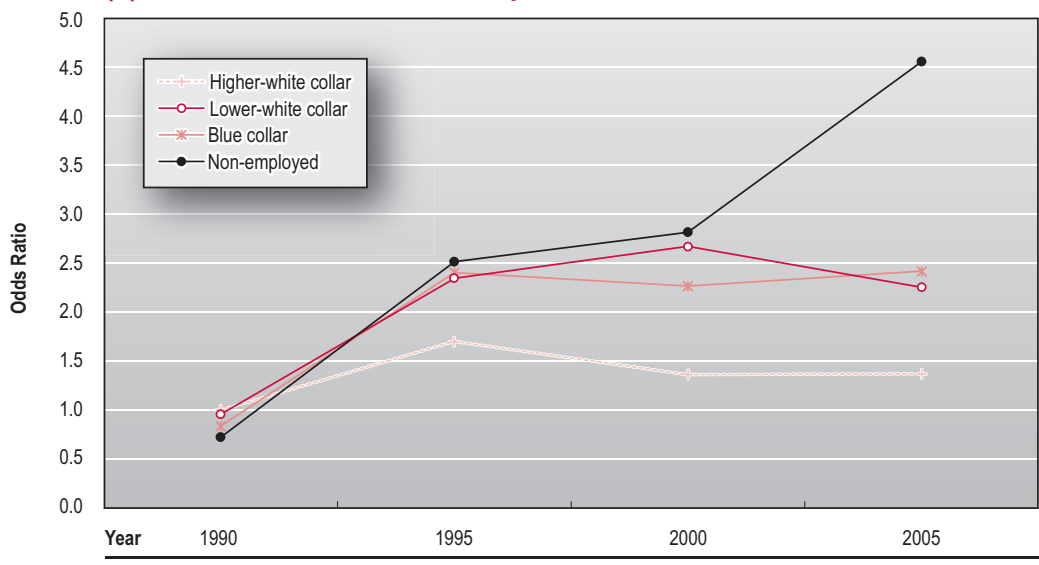

(b) Interactions between Class and Year

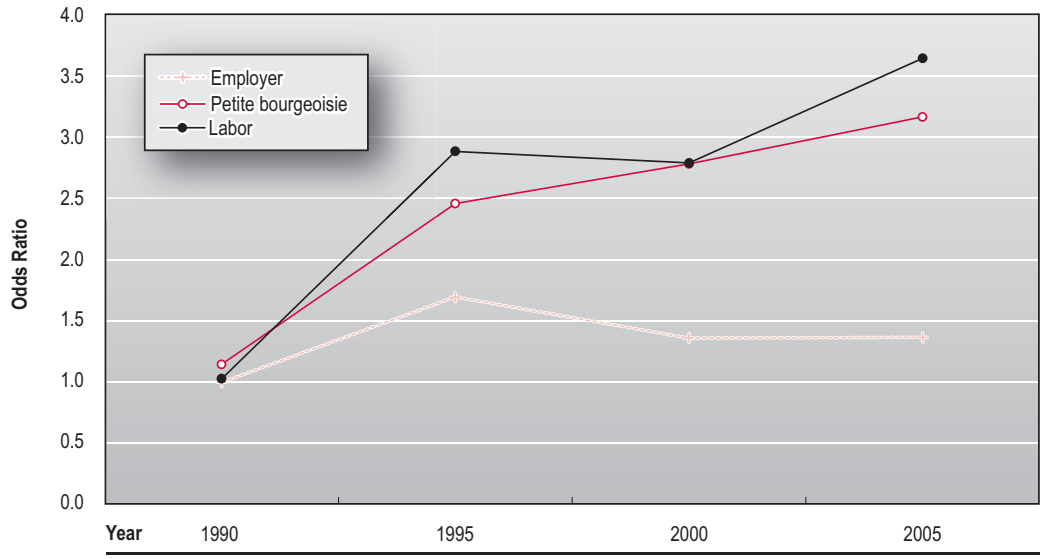

(c) Interactions between Party Inclination and Year

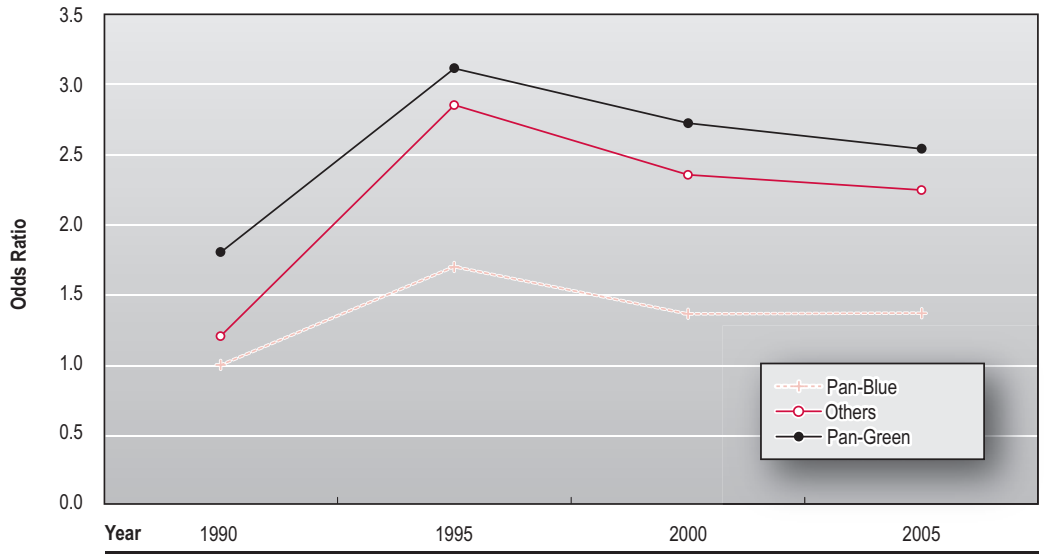

Source: Taiwan Social Change Survey. 
not belonging to the upper-middle/upper class, or those who do not favour any major political parties are more likely to express no comment for this question than their counterparts. People in socially disadvantaged positions seem to be more reserved or feel less interested in revealing their attitudes on this matter. In contrast, men and relatively conservative respondents are less likely to answer "no comment."

\section{Interaction between year, job, class, and party preference}

In this part we discuss the results of the second half of Table 2. Concerning support for union power, most of the interaction appears between party preference and year. The "no comment" (vs. less power) item was not significant, meaning that at the very least there was not any growing indifference over time. Transforming the sum of odds ratios into graphs provides a better representation of support for greater vs. less union power. ${ }^{(34)}$

Figure 4 presents graphs showing the interaction between year and occupational categories, class, and party orientations. The added odds ratios (statistics on the $Y$ axis) are the sum of the main effects of year and the predicting variables and the interaction effects between them. Thus the graphs represent the likelihood of supporting more union power as opposed to less power, considering both direct and interaction effects.

In Graph A, the higher white-collar workers are used as the compared group. ${ }^{(35)}$ For those currently not in the labour markets, the odds for supporting stronger unions increase over time. The added odds are three times higher than for upper non-manual workers in 2005. The unemployment rate reached 4 percent in that year, higher than in the previous three survey years (see Table 1 and Figure 2). Bad job market conditions may have contributed to greater support for unions in the less privileged group. Both blue-collar and lower white-collar workers were also more likely than higher white-collar workers to approve of more powerful unions in any survey year, except in 1990.

Graph B shows the results of interaction between year and class position. The disparity of added odds ratios between the reference and other groups is much larger than in Graph A. The effect of class is more obvious than that of occupation. Clearly, compared with employers, the petite bourgeoisie have much larger added odds of supporting greater union power in all years. The total odds of the working class are even higher. The results seem to be consistent with Gates's observation ${ }^{(36)}$ that the inter-mobility between workers and self-employed/small owners makes the two groups equally sympathetic to unions.
The last graph in Figure 4 shows the results of interaction between year and party orientation. The results are rather distinct, as the three lines are almost parallel with one another. Respondents voting for other parties have odds less than two times higher for supporting stronger union power than those voting Pan-Blue. The odds for the Pan-Green supporters are even higher. However the added odds of supporting stronger unionisation decreased for both DPP voters and voters with fixed party preference since 2000. We shall discuss the implications of these results in the final section.

\section{Conclusion and discussion}

Many studies have focused on how economic and political transformation affects unionisation and labour movements in newly-industrialised societies such as East Asia. ${ }^{(37)}$ Among these, Taiwan has gradually moved from Martial Law to democracy. However, an institutionalised electoral political system and individual political freedom do not guarantee distributional justice in the economy and the protection of social rights. This is where labour unions and their activities become so important in obtaining justice and improving welfare for members. At the beginning of this paper we quoted a remark by a high-ranking DPP official to illustrate the hostility of any ruling party toward labour strikes. It is ironic, since the DPP had been a major force advocating autonomous unions and the right to labour actions when it was the opposition party before 2000 . While politicians tend to cite public attitudes in denouncing union movements, this paper uses empirical data to show how people really think. According to the results of the frequency distribution, the majority of respondents wished unions to be more influential in all four survey years. Even though the figures are lower than those in Britain (51 percent in $1981^{(38)}$ ) or in the US (70 percent approval rate between the mid-1980s and

34. The odds ratio compares whether the probability of a certain event is the same for the reference (or experimental) group and the compared group (the omitted one). An odds ratio of 1 means that the probability of an event occurring is equal for both groups. An odds ratio greater than 1 implies that the event is more likely to occur for the reference group. Since we add the odds ratios of main effects and interactions together, the added result might be over 1 . Still, the larger the sum of odds ratios, the higher the likelihood of the event occurring for the reference group.

35. The readers will notice that in all three graphs in Figure 4, the odds ratios for the compared group are the same. By definition, the value for the compared group will always be zero and only the odds for different years will be left after we add interactions and main effects.

36. H. Gates, Chinese Working-Class Lives: Getting by in Taiwan, op. cit., p. 9.

37. For a seminal example, see Frederic Deyo, Beneath the Miracle: Labour Subordination in the New Asian Industrialism, Berkeley, University of California Press, 1989.

38. M. Roiser, T. Little, "Public Opinion, Trade Unions and Industrial Relations," art. cit., p. 5. 
Table 2. Multinomial Logistic Analysis of Public Attitude toward the Influence of Labor Unions (Coding of Dependent Variables: Less $=0$, Greater $=1$, No comment=2)

\begin{tabular}{|c|c|c|c|c|}
\hline \multirow{2}{*}{ Independent variables } & \multicolumn{2}{|c|}{ Greater vs. Less } & \multicolumn{2}{|c|}{ No Comment vs. Less } \\
\hline & Coefficient (S.E.) & Odds Ratio & Coefficient (S.E.) & Odds Ratio \\
\hline Male & $-.14(.07)+$ & .87 & $-.44(.09)^{* * *}$ & .64 \\
\hline Age & $-.01(.00)^{* * *}$ & & $.01(.00)^{* * *}$ & \\
\hline \multicolumn{5}{|l|}{ Ethnicities (Mainlander=0) } \\
\hline Hokkien of Taiwan & $.02(.10)$ & 1.02 & $.06(.12)$ & 1.06 \\
\hline Hakka of Taiwan & $.05(.12)$ & 1.05 & $.05(.15)$ & 1.05 \\
\hline \multicolumn{5}{|l|}{ Education (College or higher=0) } \\
\hline Primary school or less & $-.10(.13)$ & .91 & $.55(.15)^{* * *}$ & 1.74 \\
\hline Junior high school & $-.09(.12)$ & .92 & $.14(.15)$ & 1.15 \\
\hline Senior high school & $-.03(.09)$ & .97 & $-.03(.12)$ & .97 \\
\hline \multicolumn{5}{|l|}{ Occupations (Higher white-collar=0) } \\
\hline Lower white-collar & $-.05 \quad(.23)$ & .95 & $.17(.28)$ & 1.19 \\
\hline Blue-collar & $-.18 \quad(.24)$ & .83 & $-.03(.29)$ & .97 \\
\hline Non-employed & $-.33(.30)$ & .72 & $.15(.36)$ & 1.16 \\
\hline \multicolumn{5}{|l|}{ Classes (Employer=0) } \\
\hline Petite bourgeoisie & $.14 \quad(.29)$ & 1.15 & $.42(.32)$ & 1.52 \\
\hline Labor & $.03(.24)$ & 1.03 & $-.02(.28)$ & .98 \\
\hline Non-employed & & (dropped) & & (dropped) \\
\hline \multicolumn{5}{|c|}{$\begin{array}{l}\text { Subjective class identification: } \\
\text { (Upper-middle or upper class }=0 \text { ) }\end{array}$} \\
\hline Lower class & $.06 \quad(.15)$ & 1.06 & $.68(.18)^{* * *}$ & 1.98 \\
\hline Working class & $.31(.12)^{* *}$ & 1.37 & $.62(.15)^{* * *}$ & 1.86 \\
\hline Lower-middle or middle class & $.10(.09)$ & 1.11 & $.44(.12)^{* * *}$ & 1.56 \\
\hline \multicolumn{5}{|l|}{ Party orientation (Pan-Blue $=0$ ) } \\
\hline Pan-Green & $.59(.31)+$ & 1.81 & $-.15(.39)$ & .86 \\
\hline Others & $.19(.14)$ & 1.20 & $.65(.16)^{* * *}$ & 1.92 \\
\hline \multicolumn{5}{|c|}{$\begin{array}{l}\text { Whether in agreement with the saying: } \\
\text { "People will be less willing to work hard if } \\
\text { there is good social welfare." (Disagree=0) }\end{array}$} \\
\hline Agree & $-.24(.07)^{* *}$ & .78 & $-.22(.09)^{*}$ & .80 \\
\hline No comment & $.09(.15)$ & 1.09 & $.06(.18)$ & 1.06 \\
\hline Regional unemployment rate (\%) & $-.1 \mathrm{E}-2(.07)$ & & $-.08(.08)$ & \\
\hline \multicolumn{5}{|l|}{ Survey year $(1990=0)$} \\
\hline 1995 & $-.36 \quad(.38)$ & .70 & $.17(.47)$ & 1.19 \\
\hline 2000 & $-1.02(.39)^{* *}$ & .36 & $-.77(.48)$ & .46 \\
\hline 2005 & $-1.00(.43)^{*}$ & .37 & $-.90(.57)$ & .41 \\
\hline
\end{tabular}




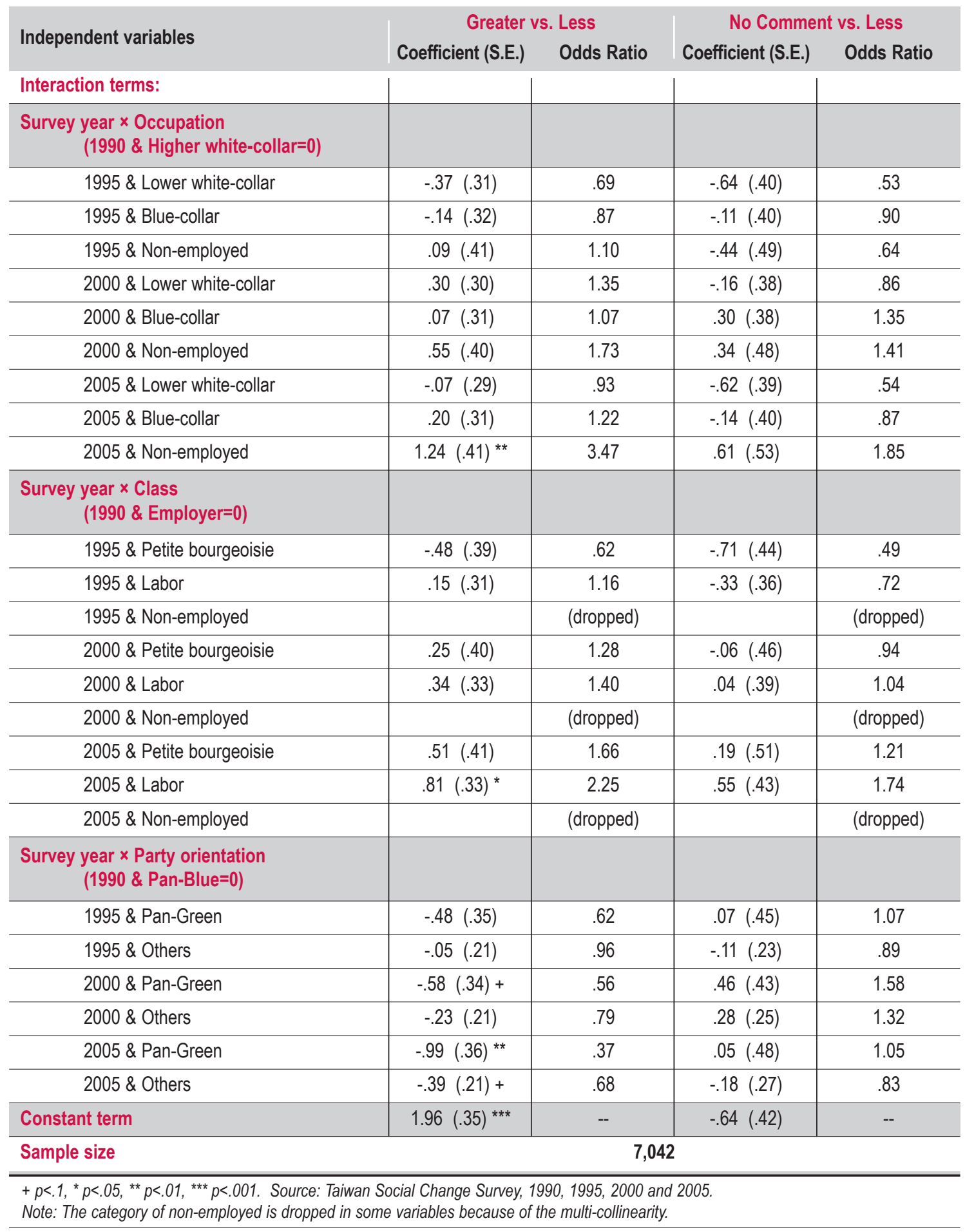

$\left.2000^{\left({ }^{39}\right)}\right)$, the results are impressive considering the short history of political democracy and relatively free unionisation in Taiwan. Majority support held true even with the rather large proportion of respondents answering "no comment."
We speculate that support for influential unions means not

39. Thomas I. Palley, Robert M. Lajeunesse, "Social Attitudes, Labour Law, and Union Organizing: Toward a New Economics of Union Density," Journal of Economic Behavior \& Organizations, vol. 62, no.2, 2007, pp. 237-254. 
only organising efforts but also legitimate action taken to protect labour rights. These results should help refute claims by politicians of public resentment of labour activities and lend some encouragement to labour activists, unions, and their members. With economic conditions deteriorating in the twenty-first century, calls for stronger unions became even louder in 2005 than the previous three surveys.

This paper also examines who supports stronger unions. The results of multivariate analyses show that opinions regarding strong unions significantly differ among classes. Strong unions are consistently support by the working class and the petite bourgeoisie, regardless of political and economic changes.

Even so, the history of political development made party preference another important factor in explaining public attitudes toward union support in Taiwan. Regardless of which year we studied, voters for Pan-Green parties were more likely to desire more influential unions than Pan-Blue voters or those with other political preferences. However, the odds decreased in 2000 and 2005. Thus, compared with PanBlue voters, those who voted Pan-Green still supported stronger unions, but with a declining trend after the DPP became the ruling party. As we indicate above, some people supported labour actions as another way to resist the rule of the KMT. DPP supporters became less enthusiastic when the KMT was ousted in the 2000 presidential election.

We acknowledge certain limitations in the paper. First, the term "labour union" used in the questionnaire is vague. It might refer to all unions or to the union the respondent belongs to. Although we believe respondents were instructed to give a general view regarding union strength, the answers would be more valid if future research clearly defines "labour unions" in the questionnaire.

Secondly, the factors used to explain attitudes toward unions are mainly the demographic characteristics and socio-economic achievements of respondents. We do not have information on why they support unions. Future research would be able to assess whether support for unions is based on personal experience or is purely support for workers' power in issues of rights or economic interests.

Finally, besides asking the degree of support for influential unions, it would be more informative to know specific aspects of union activity that members of the public support. For instance, respondents may accept union organising but not militant action against employers. The current study does not differentiate between support for activities and for the organisation per se. Thus we do not know if the public really has negative feelings regarding workers' strikes or protests, as politicians have claimed.
Although unionisation has enjoyed strong endorsement from the public over an extended period (1990 to 2005), the organisation rate of industrial unions has remained low and has even been gradually decreasing in Taiwan. About two thirds of Taiwan's employed labour force is engaged in the tertiary sector, but this sector, with a high proportion of women, has been historically under-organised. While 37 percent of the work force in the telecommunications and transportation sectors and 15.7 percent of those in manufacturing were union members by the end of the 1990s, the proportion for the service sector was only in the single digits. ${ }^{(40)}$ The unbalanced recruiting of white-collar workers is not an issue unique to Taiwan; organising efforts among workers in the US service sector are also weak. ${ }^{(4)}$ Taiwanese industrial unions have been concentrated in the traditional industries, and most of their employees are men. Only a few banks and governmental agencies have begun to establish independent unions. Our findings suggest that mobilising workers from the service sector should be crucial to building up genuine union power in Taiwan. $•$

\section{Glossary}

Fanlan 泛藍 Fanlü 泛綠 Fulao 福佬

Hau Pei-tsun 郝柏村 Kejia 客家

Lee Teng-hui 李登輝 Minnanren 閩南人

Taitie gonghui 台鐵工會

Taiwan shehui bianqian qiben diaocha 台灣社會變遷基本調查

Waishengren 外省人 Zhengfengshi 政風室

40. Web news of Taiwan Labour Front (http://labour.ngo.org.tw/labour-rights report/20report/ 1-organizing.htm; access date: 10 February 2010).

41. Rick Fantasia, Kim Voss, Hard Work: Remaking the American Labor Movement, Berkeley, CA, University of California Press, 2004 